\title{
Analisis Pemberhentian Kepala Daerah Berdasarkan Undang-Undang Nomor 23 Tahun 2014 Tentang Pemerintahan Daerah Di Indonesia
}

\author{
Azmi \\ Dosen Ilmu Administrasi Negara \\ Fakultas Ilmu Sosial dan Ilmu Politik \\ Universitas Karimun \\ alazzamazmi@gmail.com
}

\begin{abstract}
ABSTRAK
Proses pemberhentian kepala daerah berdsarkan Undang-Undang Nomor 23 tahun 2014 Tentang Pemerintahan Daerah yang pada hakikatnya Pemberhentikan kepala daerah dapat dilakukan dengan prasyaratan tententu sebagaimana yang tertuang dalam Peraturan Perundang-Undangan. Berdasarkan cacatan statistik penindakan KPK. Sepanjang Tahun 2014 sampai dengan 2019 terdapat 124 Kepala Daerah yang terjerat kasus korupsi. Di tahun 2019 sendiri terdapat sejumlah yang terjerat kasus korupsi yang diberhentikan ketika masih aktif dalam masa jabatannya. Dapat di rangkum ada 10 (sepuluh) Kepala Daerah aktif yang tersandung kasus rasuah (korupsi), mereka terdiri dari Gubernur, Bupati/Walikota. Adapun tujuan dalam penelitian ini "untuk mengetahui dan Menganalisis Proses Pemberhentian Kepala Daerah Berdasarkan Undang-Undang Nomor 23 Tahun 2014 Tentang Pemerintahan Daerah Di Indonesia". Untuk menjawab penelitian tersebut, penulis menggunakan jenis penelitian studi literatur melalui pendekatan peraturan Perundang-Undangan, konseptual dan Perbandingan, jenis dan sumber data yang digunakan yakni data Primer dan data Skunder dengan pengumpulan data yang di peroleh dari dokumentasidokumentasi yang diperoleh dari berbagai sumber. Kemudian penulis menganalisis seluruh data yang terkumpul secara deskriptif. Berdasarkan hasil penelitian yang dilaksanakan ditemukan proses substansi Pemberhentian Kepala daerah di atur dalam Undang-Undang Nomor 23 Tahun 2014 Tentang Pemerintahan Daerah, dimana pemberhentian kepala daerah hanya dapat dilakukan jika kepala daerah terbukti melanggar aturan hukum. Meskipun demikan masih terdapat penafsiran yang bersifat multitafsir terutama aturan yang terkait berupa: tidak dapat melaksankan tugas berkelanjutan atau berhalangan tetap secara berturut-turut selama enam bulan, tidak lagi memenuhi syarat kepala daerah dinyatakan melanggar sumpah atau janji jabatan kepala daerah, pengaturan mengenai mekanisme pemberhentian kepala daerah menurut UU Nomor 23 tahun 2014 sudah cukup mencangkup substansi mengenai alasan pemeberhentian kepala daerah baik dari aspek politik maupun aspek yuridis sehingga masih perlu dipertahankan.
\end{abstract}

Kata Kunci: Pemberhentian, Kepala Daerah, UU No 23 tahun 2014 


\section{Pendahuluan}

Kepala Daerah dan Wakil Kepala Daerah memiliki tugas, wewenang dan kewajiban serta larangan. Kepala Daerah juga mempunyai kewajiban untuk memberikan laporan penyelenggaraan Pemerintah Daerah kepada Pemerintah, dan memberikan laporan keterangan pertanggungjawaban kepada Dewan Perwakilan Rakyat Daerah (DPRD). Serta menginformasikan laporan penyelenggaraan Pemerintah Daerah kepada masyarakat.

Dalam sistem ketatanegaraan di Indonesia terdapat fungsi Eksekutif dan Legislatif. Hal ini tentunya sangat berkaitan erat dengan jabatan Kepala Daerah yang kinerjanya diawasi oleh Dewan Perwakilan Rakyat Daerah (DPRD), bahkan DPRD diberikan kewenangan untuk mengusulkan proses pemberhentian Kepala Daerah kepada Mahkamah Agung, hal ini tertuang dalam Undang-Undang Nomor 23 Tahun 2014 Tentang Pemerintahan Daerah, berkaitan dengan kewenangan DPRD dalam melakukan pemberhentian Kepala Daerah.

Dengan adanya proses fungsi pengawasan bahkan sampai dengan kewenangan DPRD di dalam mengajukan pemberhentian Kepala Daerah yang dianggap melakukan kesalahan-kesalahan yang bertentangan dengan regulasi yang berlaku, hal ini akan membuat kinerja Kepala Daerah cenderung profesional dan menjalankan visi dan misinya dengan baik untuk kemajuan daerah yang dipimpinnya.

Pengaturan pemberhentian sebagaimana Undang-Undang Nomor 23 Tahun 2014 Tentang Pemerintahan Daerah (Pemda) justru lebih baik dan efektif, karena Kepala Daerah yang ditetapkan sebagai tersangka dan ditahan, dilarang untuk tetap bertugas. Hal ini berbeda dengan UndangUndang Nomor 32 Tahun 2004 sebelumnya yang memperbolehkan tetap bertugas hingga Kepala Daerah tersebut menjadi terdakwa.

Perlunya pemberhentian kepala daerah yang telah ditetapkan sebagai tersangka dan ditahan atas berbagai kasus hukum yang melatarbelakanginya, memberikan kepastian penyelenggaraan pemerintahan di daerah-daerah sebagai pucuk pimpinan tertinggi di dalam roda pemerintahan daerah yang bertanggungjawab dalam pengelolaan pemerintahan. Pemberhentian kepala daerah sebagaimana diatur dalam Undang-Undang Nomor 23 Tahun 2014 Tentang Pemerintahan Daerah telah memberikan kepastian penyelenggaraan pemerintah daerah tetap berjalan walaupun kepala daerahnya tersangkut kasus hukum.

Artinya kalau Undang-Undang Nomor 32 Tahun 2004 sebelumnya itu Kepala Daerah boleh tetap memerintah, namun menjadi tidak efektif, mengapa demikian, karena bawahannya dalam segala urusan harus membawa-bawa surat ke tahanan untuk ditandatangani. Sedangkan UndangUndang Nomor 23 Tahun 2014 yang baru mengatur lebih baik dan efektif, karena Kepala Daerah yang sedang menjalani tahanan dilarang menjalankan tugas dan kewenangannya. 
Pemberhentian kepala daerah dan wakil kepala daerah dalam Undangundang Nomor 23 Tahun 2014 Tentang Pemerintahan Daerah diatur dalam Bab VII Paragraf 5, Pasal 78 sampai dengan Pasal 89. Ada pemberhentian yang melibatkan atau atas inisiatif Dewan Perwakilan Rakyat Daerah, dan ada yang tidak melalui inisiatif Dewan Perwakilan Rakyat Daerah tetapi langsung dilakukan oleh Presiden, melalui keputusan pengadilan yang sudah mempunyai kekuatan hukum tetap. Demikian juga pemberhentian ada yang merupakan pemberhentian sementara dan ada yang diberhentikan secara tetap. Pada dasarnya ada tiga alasan kepala daerah atau wakil kepala daerah berhenti, yaitu : meninggal dunia, permintaan sendiri, atau diberhentikan

\section{Tinjauan Pustaka}

\section{a. Konsep Pemeritahan}

Pemerintahan pada awalnya dibentuk untuk menghindari keadaan dimana sebuah wilayah yang dihuni oleh manusia mengalami serba kekacauan. Keadaan itu kemudian memaksa lahirnya seseorang dengan pengaruh yang ditimbulkannya untuk membentuk kelompok lain. Dalam perkembangannya kelompok inilah yang kemudian menjadi kelompok istimewa untuk melakukan apa saja bagi kepentingan perlindungan dan penyelamatan masyarakat. Kelompok tersebut pada akhirnya menjadi kelompok minoritas yang memiliki otoritas tak terbatas dengan tujuan yang dapat mereka lakukan atas nama kelompok mayoritas (rakyat) atau bahkan atas keinginan atau kehendak mereka sendiri.

Kelompok tersebut kemudian menjadi pihak yang mengklaim diri sebagai satu-satunya yang paling berhak memerintah atau "Pemerintah". Pemerintah kemudian diartikan sebagai kelompok orang yang bertanggung jawab atas penggunaan kekuasaan/exercising power (The International Encyklopedia of social science). Aktifitas Pemerintah dalam upaya memelihara kedamaian dan keamanan Negara kemudian menjadi kewenangan utama, baik secara internal maupun eksternal. Dalam keadaan demikian Max Weber menyimpulkan bahwa Pemerintah tidak lain merupakan apapun yang berhasil menopang klaim bahwa dialah yang secara eksclusif berhak menggunakan kekuatan fisik untuk memaksakan aturan-aturannya dalam suatu wilayah tertentu. Atas eksclusifisme tersebut sebuah Pemerintahan memiliki paling tidak tiga hal pokok yaitu pertama, memiliki angkatan perang mempertahankan Negaranya dari serangan dan invansi Negara lain. Kedua, Pemerintahan harus memiliki suatu lembaga yang bertanggung jawab secara legislatif dalam membuat hukum bagi proses penyelenggaraan Pemerintahan, dan Ketiga, Pemerintahan harus memiliki kemampuan keuangan yang memadai bagi upaya membiayai penyelenggaraan rumah tangga suatu Negara.

Dikatakan juga bahwa Pemerintah adalah sebuah gejala yang memperlihatkan dan menjalankan kekuasaan Negara. Kendati demikian beberapa pakar menggangap bahwa apa yang menjadi persyaratan awal pengertian di atas tentang kekuatan militer tidaklah selalu berhubungan dengan organisasi kekuatan bersenjata, tetapi dua atau sekelompok orang yang sekian banyak dipersiapkan oleh suatu organisasi dalam upaya 
mewujudkan tujuan bersama menyangkut Urusan umum kemasyarakatan cukuplah menjadi syarat dalam pengorganisasian kekuatan.

Dalam keseluruhan tersebut Pemerintah merupakan satuan yang paling umum untuk melakukan tanggung jawab tertentu guna mempertahankan Sistem serta mempertahankan monopoli praktis lewat kekuasaan secara paksa. Cenderung melihat kondisi tersebut sebagai suatu gejala kekuasaan semata, sehingga Pemerintah dipandang sah dalam melakukan intervensi secara monopoli sebagai bentuk tanggung jawab terhadap kepentingan umum.

\section{b. Konsep Pemerintahan Berdasarkan Hukum}

Pemerintahan adalah kegiatan penyelenggaraan Negara guna memberikan pelayanan dan perlindungan bagi segenap warga masyarakat, melakukan pengaturan, memobilisasi semua sumber daya yang diperlukan, serta membina hubungan baik di dalam lingkungan negara ataupun Negara lain.

Pemerintahan dalam arti luas menyangkut kekuasaan dan kewenangan dalam bidang legislatif, eksekutif dan yudikatif. Eksekutif hanyalah kegiatan Pemerintahan dalam arti sempit. Secara tradisional dipahami bahwa ada pembagian kekuasaan yang sangat tegas di antara ketiga lembaga tersebut. Legislatif melakukan pengaturan, membuat kebijaksanaan, sedangkan pihak eksekutif melaksanakan atau mengimplementasikan apa yang diatur atau yang diputuskan oleh pihak legislatif, dan kekuasaan yudikatif memberikan sanksi atas penyimpangan atau pelanggaran yang dilakukan oleh kekuasaan eksekutif terhadap apa yang sudah diputuskan oleh kekuasaan legislatif.

Menurut Jellinek dalam Maria Farida Indrati S. mengatakan bahwa: Pemerintahan mengandung dua arti yaitu arti formal dan arti materil. Pemerintahan dalam arti formal mengandung kekuasaan mengatur (Verordmnungsgewalt) dan kekuasaan memutus (Entscheidugssgewalt) sedangkan Pemerintahan dalam arti materil berisi unsur memerintah dan unsur melaksanakan (Das Elementder Reglerung Und Das Der Vollziehung).

Moh. Kusnardi dan Hermaily Ibrahim dalam Maria Farida Indrati S mengatakan bahwa pemerintahan dalam arti luas adalah segala urusan yang dilakukan oleh Negara dalam menyelenggarakan kesejahteraan rakyatnya dan kepentingan yang tidak hanya menjalankan tugas eksekutif saja, melainkan juga meliputi tugas lainnya termasuk legislatif dan yudikatif.

Uraian tentang pemerintahan di atas memberikan gambaran bahwa Pemerintahan itu terdiri dari legislatif, eksekutif dan yudikatif. Pada dasarnya penyelenggaraan sebuah Negara moderen tidak menarik garis yang tegas diantara ketiga kewenangan atau kekuasaan dari institusi yang menjalankannya. Kewenangan atau kekuasaan yang dimiliki Pemerintahan tersebut harus dijalankan berdasarkan hukum.

\section{c. Konsep Sistem Pemerintahan}


Konsep mengenai Sistem Pemerintahan ini relevan dipergunakan dalam penelitian ini. Hal ini karena Sistem Pemerintahan berkaitan erat dengan hubungan antara kekuasaan legislatif dan eksekutif, dimana diantara keduanya harus terdapat checks and balances dalam menjalankan Pemerintahan. Bentuk pengawasan yang dilaksanakan oleh legislatif terhadap penyelenggaraan Pemerintahan oleh eksekutif salah satunya berupa adanya pranata pemberhentian Kepala Daerah dan/atau Wakil Kepala Daerah. Hal ini bertujuan agar tidak ada pelanggaran-pelanggaran yang dilakukan oleh Kepala Daerah (eksekutif) dalam menyelenggarakan roda Pemerintahan.

Dengan memahami mekanisme pemberhentian Kepala Daerah dan/atau Wakil Kepala Daerah yang diatur dalam Undang-Undang Nomor 23 Tahun 2014 dan mengaitkannya dengan model-model yang ada, akan dapat diketahui model pemberhentian Kepala Daerah dan/atau Wakil Kepala Daerah yang dianut Indonesia berdasarkan Undang-Undang Nomor 23 Tahun 2014. Sistem Pemerintahan yang terdiri dari 2 (dua) kata yaitu Sistem dan Pemerintahan.

\section{d. Konsep Desentralisasi}

Desentralisasi sebagai suatu asas yang digunakan dalam bidang Pemerintahan yang merupakan kebalikan dari asas sentralisasi. Dalam asas sentralisasi kewenangan berada pada Pemerintah Pusat dan tidak distribusikan ke daerah, sehingga Pejabat-Pejabat di daerah hanyalah melaksanakan kehendak Pemerintah Pusat dalam mejalankan Pemerintahan di daerah.

Berbeda dengan asas sentralisasi, asas desentralisasi menghendaki Pemerintah Pusat memberikan sebagian kewenangannya kepada penyelenggara Pemerintahan di daerah. Istilah desentralisasi berasal dari dua kata bahasa latin, de berarti lepas dan cetrum berarti pusat. Sehingga desentralisasi secara harfiah, bermakna melepaskan diri dari pusat. Dalam presfektif kajian ketatanegaraan, Pemerintahan berdasarkan asas desentralisasi berkaitan erat dengan Pemerintah Pusat di mana Pemerintah Pusat melimpahkan sebagian kewenangannya kepada Pemerintah Daerah.

Sedangkan menurut The Liang Gie desentralisasi merupakan pelimpahan wewenang dari pemerintahan pusat kepada Satuan-Satuan Organisasi Pemerintahan untuk menyelenggarakan segenap kepentingan setempat dan kelompok penduduk yang mendiami suatu wilayah. bahwa:

Sedangkan menurut Inu Kencana Syafie dalam Madjid H. Abdullah

"Desentralisasi adalah lawan kata dari sentralisasi karena pemakaian kata "de" dimaksudkan untuk menolak kata sebelumnya. Desentaralisasi adalah penyerahan segala urusan, baik pengaturan dalam arti pembuatan Peraturan Perundang-Undangan maupun penyelenggaraan Pemerintahan itu sendiri, dari Pemerintah Pusat kepada Pemerintah Daerah, untuk selanjutnya menjadi urusan rumah tangga Pemerintah Daerah tersebut". 
Dalam berbagai referensi banyak dikemukan definisi tentang desentralisasi dari berbagai pandangan para pakar. Definisi yang kemukan oleh banyak pakar tersebut nampak secara sederhana memiliki perbedaan, namun secara substansi pada umumnya didefinisikan bahwa desentralisasi itu sebagai asas dalam penyelengaraan Pemerintahan dimana pada dasarnya adalah pembagian wewenang Pemerintahan dari Pemerintah Pusat kepada Pemerintah Daerah untuk diselenggarakan di daerah.

e. Konsep Sistem Pemerintahan Daerah

1) Pemberian Kekuasaan Yang Diberikan Pemerintah Pusat Kepada Pemerintah Daerah Dalam Peyelenggara Pemerintahan Daerah

Pasal 18 Undang-Undang Dasar 1945 merupakan dasar hukum pembentukan Pemerintahan Daerah dan penyelenggaraan otonomi daerah dengan memberikan kewenangan yang luas, nyata dan bertanggungjawab kepada daerah. Dalam menentukan kewenangan yang dimiliki oleh daerah, berlaku teori residu, kewenangan daerah merupakan sisa dari semua kewenangan setelah dikurangi lima kewenangan yang dimiliki oleh Pemerintah Pusat. Dengan demikian berarti kewenangan yang dimiliki daerah tidak terhingga, sehingga setiap daerah dapat menyelenggarakan kewenangan sebanyak-banyaknya tergantung kebutuhan dan kemampuan daerah yang bersangkutan.

Undang-Undang Nomor 2 Tahun 2015 Tentang Penetapan Peraturan Pemerintah Pengganti Undang-Undang Nomor 2 Tahun 2014 Tentang Perubahan atas UU Nomor 23 Tahun 2014 Tentang Pemerintahan Daerah melimpahkan wewenang Pemerintahan kepada Gubernur sebagai Wakil Pemerintah dan/atau kepada instansi vertikal di wilayah tertentu. Pembagian Urusan Pemerintahan di Indonesia, pada hakikatnya dibagi dalam 3 kategori, yakni Urusan Pemerintahan Absolute, Urusan Pemerintahan Konkuren, dan Urusan Pemerintahan Umum.

\section{2) Kepala Derah dan Wakil Kepala Daerah}

Kepala Daerah adalah Pimpinan Lembaga yang melaksanakan Peraturan Perundangan. Dalam wujud konkritnya, lembaga pelaksana kebijakan daerah adalah organisasi Pemerintahan. Kepala Daerah menyelenggarakan Pemerintahan didaerahnya. Kepala Daerah Provinsi disebut Gubernur, Kepala Daerah Kabupaten disebut Bupati, dan Kepala Daerah Kota disebut Walikota.

\section{3) Kedudukan Kepala Daerah Dalam Sisitem Pemerintahan Di Indonesia}

Keberadaan Kepala Daerah dapat dipahami karena adanya daerah dalam suatu Negara kesatuan. Istilah daerah digunakan untuk menunjuk pada wilayah yang hanya terdapat pada Negara kesatuan yang merupakan padanan Negara bagian pada Negara federasi. Identitas Negara kesatuan adalah satu Negara sebagaimana yang diungkapkan C.F Strong "hakikat 
Negara Kesatuan adalah Negara yang kedaulatannya tidak terbagi, atau dengan kata lain Negara yang kekuasaan Pemerintah Pusat nya tidak terbatas karena konstitusi Negara Kesatuan tidak mengakui adanya Badan Pembuat Undang-Undang Pusat. Jika kekuasaan pusat berpendapat ada baiknya mendelegasikan kekuasaan itu kepada badan-badan tambahan, apakah badan tambahan itu berupa otoritas daerah atau otoritas kolonial maka hal itu bisa saja dilakukan mengingat otoritas pusat memiliki kekuasaan penuh, bukan karena konstitusi menetapkan demikian.

Pemahaman terhadap kedudukan Kepala Daerah berkaitan sekali dengan pemahaman terhadap pengertian Daerah. Kata "Daerah" dalam literatur-literatur tata Negara dan Pemerintahan biasanya mempunyai pengertian tersendiri yang sering dipahami dengan melawankanya pada pengertian "Negara Bagian". Istilah daerah digunakan untuk menunjuk pada wilayah yang terdapat pada Negara kesatuan, sedang Negara Bagian merupakan padanannya pada Negara Federasi.

\section{4) Fungsi, Tugas, Wewenang, dan Kewajiban Kepala Daerah}

Berdasarkan Undang-Undang Dasar Negara Kesatuan Republik Indonesia Tahun 1945, Negara Indonesia adalah Negara Kesatuan. Prinsip kewenangan Negara Kesatuan tidak sama antara Pemerintahan Pusat dengan Pemerintahan Daerah. Kewenangan hanya dimiliki oleh Pemerintahan Pusat, sedangkan kewenangan Pemerintahan Daerah setelah diserahkan oleh Pemerintah Pusat berdasarkan ketentuan Peraturan Perundang-Undangan.

Penyelenggaraan Urusan Pemerintahan di daerah dilaksanakan berdasarkan azas desentralisasi, dekonsentrasi, dan Tugas Pembantuan. Pemerintahan yang melibatkan keterlibatan berbagai pihak dalam suatu daerah berdasarkan aspirasi masyarakat daerah, maka Urusan Pemerintahan yang menjadi wewenang Pemerintahan Pusat diserahkan sebagian kepada Pemerintahan Daerah untuk diurus sebagai Urusan rumah tangga sendiri. Penyerahan Urusan Pemerintahan kepada daerah untuk mengatur dan mengurus rumah tangganya disebut dengan desentralisasi.

\section{5) Peran Dewan Perwakilan Rakyat Daerah (DPRD) Berdasarkan Undang-Undang Nomor 23 Tahun 2014 Tentang Pemerintahan daerah}

Dewan Perwakilan Rakyat Daerah, selanjutnya disingkat DPRD, merupakan Lembaga Perwakilan Rakyat Daerah dan merupakan salah satu unsur penyelenggara Pemerintah Daerah di samping Pemerintah Daerah. DPRD memiliki tiga fungsi utama, yaitu.

a. Fungsi pembentukan Peraturan Daerah.

b. Fungsi anggaran, dan

c. Fungsi pengawasan, yaitu melakukan pengawasan terhadap jalannya pemerintahan dan pelaksanaan Peraturan PerundangUndangan. 
Berdasarkan ketiga fungsi tersebut di atas, DPRD mempunyai tugas dan wewenang yaitu :

a. Membentuk Peraturan Daerah (Perda), bersama Kepala Daerah

b. Membahas dan memberikan persetujuan Rencangan Peraturan Daerah tentang APBD yang diajukan Kepala Daerah.

c. Melaksanakan pengawasan terhadap pelaksanaan Perda dan APBD

d. Memilih Kepala Daerah.

e. Mengusulkan pengangkatan dan pemberhentian Kepala Daerah/Wakil Kepala Daerah kepada Presiden melalui Menteri untuk mendapatkan pengesahan pengangkatan dan pemberhentian.

f. Memberikan pendapat dan pertimbangan kepada Pemerintah Daerah terhadap rencana perjanjian internasional di daerah.

g. Memberikan persetujuan terhadap rencana kerja sama internasional yang dilakukan oleh Pemerintah Daerah

h. Meminta laporan ketenrangan pertanggungjawaban Kepala Daerah dalam penyelenggaraan Pemerintah Daerah.

i. Memberikan persetujuan terhadapa rancangan kerjasama daerah lain atau dengan pihak ketiga yang membebani masyarakat dan daerah

j. Melaksanakan tugas dan wewenang lain yang diatur dalam ketentuan Peraturan Perundang-Undangan

\section{f. Konsep Pemberhentian Kepala daerah Dalam Masa Jabatannya Menurut Undangan-Undang Nomor 23 tahun 2014}

Dalam Sistem Presidensial, Presiden sebagai Kepala Negara/Kepala Pemerintahan, pada dasarnya tidak dapat diberhentikan sebelum berakhir masa jabatannya, terkecuali dengan alasan-alasan tertentu. Hal ini juga berlaku bagi Kepala Daerah dan Wakil Kepala Daerah pada dasarnya tidak dapat diberhentikan sebelum berakhir masa jabatannya. Terkecuali sebagaimana diatur dalam Pasal 78 Ayat (1) Undang-Undang Nomor 23 Tahun 2014 Tentang Pemerintahan Daerah, yaitu apabila :

a. Meninggal dunia

b. Permintaan sendiri: atau

c. Diberhentikan

Kepala Daerah dan/atau Wakil Kepala Daerah diberhentikan sebagaimana dimaksud pada ayat (1) Pemberhentian, sebagaimana dimaksud pada huruf (c) di atas dapat dilakukan karena :

a. Berakhir masa jabatannya;

b. Tidak dapat melaksanakan tugas secara bekelanjutan atau berhalangan tetap secara berturut-turut selama (6) enam bulan 
c. Dinyatakan melanggar sumpah/janji jabatan Kepala Daerah dan Wakil Kepala Daerah.

d. Tidak melaksanakan kewajiban Kepala Daerah dan Wakil Kepala Daerah sebagaimana dimaksud dalam Pasal 67 huruf b;

e. Melanggar larangan bagi Kepala Daerah dan Wakil Kepala Daerah sebagaimana dimaksud dalam Pasal 76 ayat (1) kecuali huruf c, huruf $i$, dan huruf $j$;

f. Melakukan perbuatan tercela;

g. Diberi tugas dalam jabatan tertentu oleh Presiden yang dilarang untuk dirangkap oleh ketentuan Peraturan Perundang-Undangan

h. Menggunakan dokumen dan/atau keterangan palsu sebagai keterangan pada saat pencalonan Kepala Daerah/Wakil Kepala Daerah berdasarkan pembuktian dari lembaga yang berwenang menerbitkan dokumen; dan/atau

i. Mendapatkan sanski pemberhentian.

\section{g. Ulasan Karya}

Berdasarkan hasil telaah kepustakaan yang telah dilakukan, ada beberapa hasil ulasan karya yang berhubungan dengan penelitian ini yaitu:

1. Penelitian yang dilakukan oleh Darwin Botutihe, 2009 dengan judul "Tinjauan Hukum Tentang Pemberhentian Kepala Daerah dan Wakil Kepala Daerah."

2. Penelitian yang dilakukan oleh M. Sadmi Al Qayum, 2014 dengan judul "Mekanisme Pemberhentian Kepala Daerah Berdasarkan Undang-Undang Nomor 32 Tahun 2004 Tentang Pemerintahan Daerah (Studi Kasus Pemberhentian Bupati Garut Pada Tahun 2013)."

3. Penelitian yang dilakukan oleh Putu Eva Ditayani Antari, 2014 dengan judul "Pemberhentian Presiden dan/atau Wakil Presiden Dalam Masa Jabatannya Dalam Kaitannya Dengan Upaya Mewujudkan Negara Hukum Demokratis Di Indonesia."

4. Penelitian yang dilakukan oleh Azmi, 2017 dengan Judul "Analisis Pemberhentian Kepala Daerah Berdasarkan Undang-Undang Nomor 23 Tahun 2014 Tentang Pemerintahan Daerah Di Indonesia" Berdasarkan hasil penelitian yang dilaksanakan ditemukan proses substansi Pemberhentian Kepala daerah di atur dalam UndangUndang Nomor 23 Tahun 2014 Tentang Pemerintahan Daerah, dimana pemberhentian kepala daerah hanya dapat dilakukan jika kepala daerah terbukti melanggar aturan hukum. Meskipun demikan masih terdapat penafsiran yang bersifat multitafsir terutama aturan yang terkait berupa: tidak dapat melaksankan tugas berkelanjutan atau berhalangan tetap secara berturut-turut selama enam bulan, tidak lagi memenuhi syarat kepala daerah dinyatakan melanggar sumpah atau janji jabatan kepala daerah, pengaturan mengenai mekanisme pemberhentian kepala daerah 
menurut UU Nomor 23 tahun 2014 sudah cukup mencangkup substansi mengenai alasan pemeberhentian kepala daerah baik dari aspek politik maupun aspek yuridis sehingga masih perlu dipertahankan.

\section{Metode Penelitian}

\section{a. Jenis Penelitian}

Penelitian ini termasuk jenis penelitian studi literatur dengan mencari referensi teori yang relefan dengan kasus atau permasalahan yang ditemukan.

\section{b. Pendekatan yang dipergunakan}

Pendekatan yang di perggunakan dalam penelitian ini adalah:

1. Pendekatan Peraturan Perundang-Undangan (statue approach) yaitu dengan mengkaji Peraturan Penrundang-Undangan yang relevan dengan masalah yang di bahas.

2. Pendekatan konseptual (conceptual approach) yang mengkaji pandangan para ahli yang berkaitan dengan pokok masalah yang dibahas.

3. Pendekatan perbandingan (comparative approach) dilakukan dengan membandingkan antara Undang-Undang yang satu dengan yang lainnya yang berkaitan dengan Pemerintahan Daerah

\section{c. Jenis Sumber data}

Jenis dan sumber data dalam penelitian ini adalah data primer dan sekunder.

1. Data Primer yakni data-data yang berhubungan erat dengan permasalahan yang di teliti

2. Data Sekunder, yakni data-data yang memberikan penjelasan atau membahas lebih hal-hal yang diteliti

\section{d. Teknik Pengumpulan Data}

Teknik pengumpulan data dilakukan dengan menginventaris, menyusun berdasarkan subyek, selanjutnya dikaji/atau di pelajari kemudian diklasifikasi sesuai dengan pokok masalah yang dibahas dalam penelitian ini teknik pengumpulan bahan hukum menurut Winarno Sukahman disebut teknik studi dokumentasi dengan menggunakan alat bantu kartu titipan (card system) berdasarkan pengarang/ penulis (subyek) maupun tema atau pokok masalah (obyek) .

\section{e. Analisa Data}

Setelah selurh data terkumpul selanjutnya diklasifikasi seemikian rupa selanjutnya dianalisis secara deskriptif analitik untuk mendapatkan jawaban dari permasalahan penelitiaan. Data-data tersebut dianalisis dengan pemaparan secara sistematis dan runtut dengan teknik argumnetatif. Terhadap ketentuan yang tidak jelas ditafsirkan sesuai metode interpretasi. 
84 | Azmi. Analisis Pemberhentian...

Interpretasi yang digunakan adalah penalaran analogi dan penalaran acontrario

\section{Pembahasan}

a. Proses Pemberhentian Kepala derah Bedasarkan UndangUndang nomar 23 Tahun 2014 Tentang Pemerintahan Daerah 1) Proses Pemberhentian Kepala Daerah Dalam Kasus Korupsi

Pelaksanaan pemberhentian kepala daerah dan wakil kepala daerah yang layak dalam penyelenggaraan pemerintahan di daerah, tidak terlepas dari faktor-faktor yang dapat mempengaruhinya sehingga berdampak tidak terwujud pelaksanaan pemberhentian kepala daerah dan wakil kepala daerah yang layak. Pelaksanaan pemberhentian kepala daerah dan wakil kepala daerah secara umum tidak dapat dipisahkan dari peran lembaga penyelenggara pemerintahan di daerah seperti DPRD

\section{2) Tindak Pidana Korupsi}

Berdasarkan 10 kepala daerah yang tersandung kasus korupsi dan diberhentikan sebagai kepala daerah baik itu gubernur maupun bupati/walikota seluruhnya didakwa melanggar Undang - Undang Nomor 20 Tahun 2001 Tentang Perubahan atas Undang - Undang Nomor 31 Tahun 1999 Tentang Pemberantasan Tindak Pidana Korupsi (UU PTPK). Tindak pidana korupsi dikelompokkan menjadi 7 macam. Adapun penjelasannya adalah sebagai berikut :
a. Perbuatan yang Merugikan Negara
b. Suap - Menyuap
c. Penyalahgunaan Jabatan
d. Pemerasan
e. Korupsi yang berhubungan dengan Kecurangan
f. Korupsi yang berhubungan dengan pengadaan
g. Korupsi yang berhubungan dengan gratifikasi (Hadiah)

\section{3) Syarat Pemberhentian Kepala Daerah}

Syarat pemberhentian kepala daerah (dan atau wakil kepala daerah) baik mengenai alasan-alasan, proses dan prosedur, lembaga yang terkait beserta implikasinya baik implikasi di bidang yuridis maupun politik. Pengaturan mengenai pemberhentian Kepala Daerah diatur dalam UndangUndang Nomor 23 Tahun 2014 tentang Pemerintahan Daerah terdapat pada Bab VII Bagian Ketiga Paragraf 5, Pasal 78 sampai dengan Pasal 89, sedang tindakan penyelidikan terhadap Kepala Daerah dan Wakil Kepala Daerah diatur dalam Paragraf 6 Pasal 90.

Dengan demikian pemberhentian Kepala Daerah dan/atau kepala daerah, dilaksanakan dengan mengacu pada ketentuan, yakni sebagai berikut:

a. Melanggar sumpah / janji. 
b. Melakukan tindak pidana yang diancam pidana penjara lima tahun atau Lebih.

c. Melakukan Tindak pidana korupsi, Tindak pidana Terorisme, Makar, dan /atau Tindak Pidana Terhadap keamanan Negara

d. Menghadapi krisis kepercayaan

e. Tindakan penyidikan

\section{b. Tata Cara Pemberhentian Kepala Daerah}

Prosedur atau mekanisme pemberhentian kepala daerah yang sesuai dengan Undang-Undang Nomor 23 Tahun 2014 tentang pemerintahan daerah. Mekanisme pemberhentian kepala daerah mengalami beberapa tahapan dalam perjalanannya dan juga melewati aspek hukum dan politik. Sesuai dengan Undang-Undang Nomor 23 Tahun 2014, pemberhentian dibedakan menjadi beberapa alur sesuai dengan pelanggaran yang dilakukan oleh kepala daerah dan/atau wakil kepala daerah.

Pada Pasal 79 Undang-Undang Nomor 23 Tahun 2014 dijelaskan:

(1) Pemberhentian kepala daerah dan/atau wakil kepala daerah sebagaimana dimaksud dalam Pasal 78 ayat (1) huruf a dan huruf b serta ayat (2) huruf a dan huruf b diumumkan oleh pimpinan DPRD dalam rapat paripurna dan diusulkan oleh pimpinan DPRD kepada Presiden melalui Menteri untuk gubernur dan/atau wakil gubernur serta kepada Menteri melalui gubernur sebagai wakil Pemerintah Pusat untuk bupati dan/atau wakil bupati atau wali kota dan/atau wakil wali kota untuk mendapatkan penetapan pemberhentian.

(2) Dalam hal pimpinan DPRD tidak mengusulkan pemberhentian kepala daerah dan/atau wakil kepala daerah sebagaimana dimaksud pada ayat (1), Presiden memberhentikan gubernur dan/atau wakil gubernur atas usul Menteri serta Menteri memberhentikan bupati dan/atau wakil bupati atau wali kota dan/atau wakil wali kota atas usul gubernur sebagai wakil Pemerintah Pusat.

(3) Dalam hal gubernur sebagai wakil Pemerintah Pusat tidak mengusulkan pemberhentian bupati dan/atau wakil bupati atau wali kota dan/atau wakil wali kota sebagaimana dimaksud pada ayat (2), Menteri memberhentikan bupati dan/atau wakil bupati atau wali kota dan/atau wakil wali kota.

\section{c. Peraturan Pemberhentian Kepala daerah}

Peraturan yang dimaksud dalam penelitian ini adalah petunjuk yang dibuat untuk mengatur pemberhentian kepala daerah dan wakil kepala daerah. Secara umum peraturan tersebut adalah pengaturan yang terdapat dalam peraturan perundang-undangan yang berlaku positif di Indonesia yang ada hubungannya pemberhentian kepala daerah dan wakil kepala daerah. 
Dalam UU No 23 tahun 2014, pemberhentian kepala daerah diatur dalam Paragraf Kelima mulai Pasal 78 hingga Pasal 92. Pengaturan lebih lanjutnya ketentuan dalam UU No. 23 tahun 2014 ini diatur dalam peraturan pemerintah. Pengaturan dalam peraturan pemerintah ini di lakukan karena peraturan pemerintah memiliki fungsi untuk mengatur baik yang dengan tegas-tegas disebutkan oleh undang-undang untuk diatur dalam peraturan pemerintah maupun yang tidak tegas-tegas disebutkan.

Berdasarkan fakta yang ditemukan dalam objek penelitian penulis, kepala daerah dan wakil kepala daerah yang diberhentikan dari jabatannya. Olehnya, penulis menelaah aturan-aturan yang mengatur tentang pemberhentian kepala daerah dan wakil kepala daerah Dalam UU No. 23 Tahun 2014 tentang Pemerintahan Daerah paragraf kelima Pasal 78.

Pemberhentian kepala daerah dan wakil kepala daerah sebagaimana diatur dalam UU No 23 tahun 2014 hanya dapat dilakukan dengan syarat kepala daerah dan wakil kepala daerah tersebut meninggal dunia, mengundurkan diri atau permintaan sendiri dan diberhentikan.

\section{d. Manajemen Pemerintahan}

Pemerintah dalam menyelenggarakan pemerintahan berlandaskan kepada peraturan perundangan yang kemudian diatur sedemikian rupa sehingga menjadi suatu sistem yang dijadikan pedoman penyelenggaraan pemerintahan. Begitu juga dalam melaksanakan pemberhentian kepada seorang kepala daerah, pemerintah memiliki konsep manajemen pemerintahan agar tidak terjadi kekacauan dan pemerintahan tetap berjalan sebagaimana mestinya.

Seorang Kepala Daerah dan/atau Wakil Kepala Daerah diberhentikan sementara oleh Presiden tanpa melalui usulan DPRD apabila, Kepala Daerah dan/atau Wakil Kepala Daerah didakwa melakukan tindak pidana kejahatan yang diancam dengan pidana penjara paling singkat lima tahun, tindak pidana korupsi, tindak pidana terorisme, makar, tindak pidana terhadap keamanan Negara, dan/atau perbuatan lain yang dapat memecah belah Negara Kesatuan Republik Indonesia.

\section{e. Budaya Politik}

Pemberhentian kepala daerah dan wakil kepala daerah dengan alasan melanggar sumpah/janji jabatan dan tidak melaksanakan kewajiban sebagai kepala daerah dan wakil kepala daerah melalui proses dari DPRD. DPRD anggotanya berasal dari partai politik yang terpilih melalui pemilihan umum secara langsung. Sikap DPRD yang terhadap pemberhentian kepala daerah dan wakil kepala daerah dengan alasan melanggar sumpah/janji jabatan adalah cita-cita dari partai politik anggota DPRD. 


\section{Kesimpulan Dan Saran}

\section{a. Kesimpulan}

Proses substansi pemberhentian kepala Daerah di atur dalam UndangUndang Nomor 23 Tahun 2014 Tentang Pemerintahan Daerah. Dari undangundang tersebut substansi pemberhentian kepala daerah hanya dapat di lakukan jika kepala daerah terbukti melanggar aturan hukum. Meskipun demikian masih terdapat penafsiran yang bersifat multitafsir terutama aturan yang terkait berupa: Tidak dapat melaksanakan tugas secara berkelanjutan atau berhalangan tetap secara berturut-turut selama enam bulan, tidak lagi memenuhi syarat sebagai kepala daerah, dinyatakan melanggar sumpah atau janji jabatan kepala daerah.

Pengaturan mengenai mekanisme pemberhentian kepala daerah menurut UU Nomor 23 Tahun 2014 Tentang Pemerintahan Daerah sudah cukup memcakup substansi mengenai alasan pemberhentian kepala daerah baik dari aspek politik maupun dari aspek yuridis sehingga masih perlu dipertahankan.

\section{b. Saran}

Walaupun mekanisme pemberhentian kepala daerah tetap mengacu pada substansi hukum, Dewan Perwakilan Rakyat Daerah tetap diberi kewenangan untuk melakukan inisiatif pemberhentian, untuk menunjukkan peran yang seimbang antara organ legislatif dan organ eksekutif dalam kerangka check and balances.

\section{DAFTAR PUSTAKA}

\section{BUKU}

Anwar Hanim, Sendi-Sendi Hukum Administrasi Negara, Gelora Madani Pres. Jakarta: 2004.

Aslim Rasyad, Metode IImiah: Persiapan Bagi Peneliti, UNRI Pres, Pekanbaru: 2005.

Budiardjo, Dasar-dasar Ilmu Politik (Edisi Revisi), Gramedia Pustaka Utama, Jakarta. 2008.

Buku Pedoman Penulisan Tesis Progam Studi Magister Ilmu Pemerintahan. Universitas Islam Riau Pekanbaru. 2014.

Bungin, Burhan, Penelitian Kualitatif Komunikasi, Ekonomi, Kebijakan Publik, dan IImu Sosial Lainnya, Kencana Prenada Media Group. Jakarta, 2010.

Burhan Ashsofa, Metode Penelitian Hukum, Rineka Cipta, Jakrta: 1996.

Djamali R. Abdoel, Pengantar Hukum Indonesia, Raja Grafindo Persada, Jakarta. 2006. 
88 | Azmi. Analisis Pemberhentian...

Hanif Nurcholis, Teori dan Praktik Pemerintahan dan Otonomi Daerah, Edisi Revisi, PT Grasindo, Jakarta, 2005.

Hasibuan, Malayu, SP. Manajemen Sumber Daya Manusia, Bumi Aksara. Jakarta: 2009.

Herman Finer, Major Goverment of Modern Europe, Harper \& Row Publisher, New York. 1962.

Indrayana Deny, Negara antara Ada dan Tiada: Reformasi Hukum Ketatanegaraan, Penerbit Buku Kompas, Jakarta. 2008.

Jimly, Asshiddiqie, Pokok-pokok Hukum Tata Negara Indonesia Pasca Reformasi, Buana Ilmu Populer, Jakarta. 2007.

Jimly, Asshiddiqie, Konsolidasi. Jakarta, Sekertariat Jenderal dan Kepaniteraan MKRI, 2006.

Jimly, Asshiddiqie, Pergumulan Peran Pemerintah dan Parlemen dalam Sejarah (Telaah Perbandingan Konstitusi Berbagai Negara), UI-Press, Jakarta. 1996.

Kaloh, Mencari Bentuk Otonomi Daerah, Jakarta : Rineka Cipta, 2002.

Labolo Muhadam. Memahami Ilmu Pemerintahan Suatu Kajian Teori Konsep Dan Pengembangannya, Raja Grafindo Persada. Jakarta: 2011.

Mahfud M.D. Dasar dan Struktur Ketatanegaraan Indonesia, Rineka Cipta, Jakarta. 2001.

Manan Bagir, Lembaga Kepresidenan, FH UII Press, Yogyakarta. 2003.

Manullang M. Beberapa Aspek Administrasi Pemerintahan Daerah, Pembangunan, Jakarta: 1973.

Max Boli Sabon, Hukum Otonomi Daerah, Universitas Atma Jaya, Jakarta: 2011.

Moeleong. J. Lexy, Metodologi Penelitian Kualitatif. Remaja Rasdakarya. Bandung: 2000.

Noeng Muhajir, Metodologi Penelitian Kualitatif. Rake Sarasin. Yogyakarta. 2000.

Prayudi, Hukum Administrasi Negara, Ghalia Indonesia. Jakarta: 2009.

Rosjidi Ranggawidjaja, Pengantar Ilmu Perundang-undangan Indonesia, Penerbit Mandar Maju, Bandung, 1998.

Rozali Abdullah, Pelaksanaan Otonomi Luas Dengan Pemilihan Kepala Daerah Langsung, Raja Grafindo, Jakarta: 2007.

R. Kranenburg \& W. G. Vegting, Inleiding in het Nederlands Administratief Recht, Yayasan Badan Penerbit Gajah Mada, Yogyakarta. 1958.

R.M. Mac Iver, The Modern State, Oxford University Press, London. 1926 
Azmi. Analisis Pemberhentian... | 89

Saldi Isra, Pergeseran Fungsi Legislasi Menguatnya Model Legislasi Parlementer dalam Sistem Presidensial Indonesia, Raja Grafindo Persada, Jakarta. 2010.

Siangarimbun, Masri, dan Effendi Sofian, Metode Penelitian Survai, LP3ES. Jakarta. 1989.

Sjahnan H.R., Pelaksanaan Tata Pemerintahan dan Otonomi Menurut UUD 1945 di Indonesia, Monora, Medan 1992.

Soerjono Soekanto, Sri Mamudji. Penelitian Hukum Normatif, Suatu Tinjauan Singkat, Raja Grafindo Jakarta: 2003.

Soerjoeno Soekanto, Pengantar Penelitian Hukum, UII Pres, Jakarta: 1983.

Sri Soemantri Martosoewignjo, Pengantar Perbandingan antar Hukum Tata Negara, CV. Rajawali, Jakarta. 1981.

Stroink, Pemahaman Tentang Dekonsentrasi, Refika Aditama, Bandung, 2006.

Strong, C.F. Modern Political Constitutions, An Introduction to The Comparative Study Of Their History and Existing Form, London:Sidwick \& Jaksaon, 1963.

Sunarno Siswanto, Hukum Pemerintahan Daerah di Indonesia, Sinar Grafika, Jakarta. 2009.

Usep Ranawijaya, Hukum Tata Negara Indonesia: Dasar-Dasarnya, Ghalia Indonesia, Jakarta. 1983.

Widjaja Haw. Penyelenggaraan Otonomi Di Indonesia, Raja Grafindo, Jakarta: 2005.

Winarno Surachmad, Pengantar Penelitian Ilmiah Dasar. Erlangga. Jakarta: 1989.

Wirjono Prodjodikoro, Asas-asas Hukum Tata Negara di Indonesia, Dian Rakyat, Jakarta. 1970.

Yuda Hanta A.R., Presidensialisme Setengah Hati dari Dilema ke Kompromi, Gramedia Pustaka Utama, Jakarta. 2010.

\section{TESIS/SKRIPSI/JURNAL/KAMUS/MAKALAH :}

Al Qayum M. Sadmi, 2014. Mekanisme Pemberhentian Kepala Daerah Berdasarkan Undang-Undang Nomor 32 Tahun 2004 Tentang Pemerintahan Daerah (Studi Kasus Pemberhentian Bupati Garut Pada Tahun 2013). Jurnal Fakultas Hukum Volume I

Antari Putu Eva Ditayani, 2014. Pemberhentian Presiden dan/atau Wakil Presiden Dalam Masa Jabatannya Dalam Kaitannya Dengan Upaya Mewujudkan Negara Hukum Demokratis Di Indonesia. Tesis Pada Program Pasca Sarjana Universitas Udayana Denpasar.

Botutihe Darwin, 2009. Tinjauan Hukum Tentang Pemberhentian Kepala Daerah dan Wakil Kepala Daerah. Tesis Pada Program Pascasarjana Universitas Hasanuddin Makassar. 
$90 \mid$ Azmi. Analisis Pemberhentian...

I Nengah Suriata, Fungsi Kepala Daerah Dalam Penyelenggaraan Pemerintahan Daerah Sesuai Dengan Prinsip-Prinsip Demokrasi, Tesis Program Pasca Sarjana Universitas Udayana Denpasar, 2011.

Kamus Besar Bahasa Indonesia, 1995: Balai Pustaka, Jakarta Longman Dictionary of Centemporary English, 1989 Logman :Group Limited.

Muhammad Bahrul Ulum, 2013 "Proses Pemakzulan Kepala Daerah" Artikel pada Jurnal Hukum, 21 November 2013.

Porter, David O. dan Eugene A. Olsen, Some Critical Issue in goverment Centralization adn Decentralization, Public Administration Review, Januari/Februari 1976.

Rudianto, Peran DPRD Dalam Pemberhentian Kepala Daerah, Tesis Pada Program Pascasarjana Universitas Islam Indonesia, Yogyakarta, 2008.

\section{PERATURAN PERUNDANG-UNDANGAN}

Undang-Undang Dasar Negara Republik Indonesia Tahun 1945.

Undang-Undang Nomor 32 Tahun 2004 Tentang Pemerintahan Daerah

Undang-Undang Nomor 23 Tahun 2014 Tentang Pemerintahan Daerah.

Peraturan Pemerintah No 6 Tahun 2005 Tentang Pemilihan, Pengesahan Pengangkatan, Pemberhentian Kepala Daerah dan Wakil Kepala Daerah Lembaran Negara Republik Indonesia Tahun Nomor 2000 Tambahan Lembaran Negara Republik Indonesia Nomor 4480.

\section{SUMBER WEBSITE DAN INTERNET}

http://www.hukumonline.com/berita/baca/It54afebb14ae5a/ini-10-kepaladaerah-yang-tersandung-korupsi-di-2014. Di Akses pada tanggal 20 Januari 2016.

http://www.ut.ac,id/htm/sumplemen/adpu4440/pemerintahan_daerah.htm.di akses pada tanggal 6 Februari 2016.

https://databoks.katadata.co.id/datapublish/2019/07/13/sejak-2004-hingga2019-terdapat-124-kepala-daerah-terjerat-korupsi

\section{MAJALAH/BULETIN/SURAT KABAR}

Gamawan Fauzi "Pemberhentian Kepala Daerah: Tempo Pos, 21 Maret 2013. 